Historia Slavorum Occidentis

2020, nr $3(26)$

ISSN 2084-1213

DOI: $10.15804 /$ hso200303

GrZegorz KuCharcZyK (WarsZaWa)

ORCID: 0000-0002-3046-7555

\title{
„Germański chaos”? Niemcy i Prusy w okresie Wiosny Ludów w ocenie Juana Donoso Cortesa
}

Słowa kluczowe: Juan Donoso Cortes, konserwatyzm, Królestwo Prus, Wiosna Ludów

Keywords: Juan Donoso Cortes, conservatism, the Kingdom of Prussia, the Revolutions of 1848

\begin{abstract}
Juan Donoso Cortes was a prominent representative of the counter-revolutionary traditional school of thought. As a Spanish envoy in Berlin in 1849, he was a keen observer of the political turmoil related to the course of the Revolutions of 1848 in the Hohenzollern monarchy and the entire German Confederation.
\end{abstract}

Juan Donoso Cortes (1809-1853) należał do najwybitniejszych przedstawicieli dziewiętnastowiecznej tradycjonalistycznej myśli politycznej. Literatura przedmiotu poświęcona jego intelektualnemu dorobkowi jest pokaźna ${ }^{1}$. Celem niniejszego artykułu jest przedstawienie obserwacji i analiz, których hiszpański myśliciel dokonywał w odniesieniu do Prus i Związku Niemieckiego w przełomowym dla obu

1 W języku polskim podstawowym opracowaniem w tym zakresie jest rozdział poświęcony myśli politycznej Donoso Cortesa w dziele J. Bartyzela, „Umierać, ale powoli”. O monarchistycznej $i$ katolickiej kontrrewolucji w krajach romańskich 1815-2000, Kraków 2006, s. 351-387. Omówienie literatury przedmiotu dotyczącej myśli politycznej J. Donoso Cortesa w: B. Szlachta, Między tym, co popularne a tym, co zdrowe. Uwagi o krytykach ( $i$ koncepcjach) politycznych Donoso Cortesa, [w: ] J. Donoso Cortes, O katolicyzmie, liberalizmie i socjalizmie. Wybór pism, tłum. M. Wójtowicz-Wcisło, oprac. Zespół Ośrodka Myśli Politycznej, Kraków 2017, s. XXXVII-XXXVIII; J. Bartyzel, „Umierać, ale powoli”, s. 382. 
tych bytów politycznych okresie, jakim była Wiosna Ludów. Okazją ku temu stało się pełnienie przez Donoso Cortesa w latach 1848-1849 obowiązków posła hiszpańskiego w Berlinie 2 . Pobyt J. Donoso Cortesa nad Sprewą zaowocował zbiorem jego obserwacji dotyczących nie tylko współczesnych przemian politycznych w monarchii Hohenzollernów (czy szerzej: w Niemczech), ale również stał się dla niego asumptem do formułowania ocen dotyczących historii tego państwa, a konkretniej: tajemnicy systematycznego wzrostu jego znaczenia - od lennika Rzeczypospolitej po jedno z najważniejszych mocarstw europejskich. Opublikowana w $1862 \mathrm{r}$. polityczna korespondencja hiszpańskiego posła w Berlinie jest podstawą źródłową niniejszego artykułu ${ }^{3}$.

Hiszpański dyplomata wskazywał w tym kontekście na dwa podstawowe czynniki: „państwotwórczą” rolę dynastii Hohenzollernów oraz protestantyzm. „Prusy są cudem w historii narodów, a ród ich władców jest cudem w historii Domów panujących. Wszystkie narody, wszystkie rodziny [panujące] dochodziły do wielkości jasno wytyczoną drogą. Tylko Prusy oraz ich władcy szli do niej wszystkimi ścieżkami poprzez traktaty, podboje, wojny, nabytki, a nawet poprzez klęski. Jeśli nie wznosili się dzięki swoim wielkim cnotom, rośli dzięki wielkim niegodziwościom, jeśli ich wzrost nie był dziełem narodu, przychodził od królów. Aby wznieść się na poziom, na którym ich obecnie widzimy, z równym powodzeniem wspierali się na absolutyzmie jak i obecnie na rewolucji” ${ }^{4}$. W swoich analizach hiszpański autor podkreśla znaczenie dla przyszłej wielkości Prus panowania Wielkiego Elektora (Fryderyka Wilhelma w latach 1640-1688) oraz pierwszej koronacji królewskiej Hohenzollernów w 1701 r. Zwracał uwagę na to, że zgoda cesarza Józefa I Habsburga na wyniesienie elektora brandenburskiego i księcia pruskiego do godności królewskiej (jako Fryderyka I) była jednym z najpoważniejszych błędów polityki wiedeńskiej. Od tego czasu bowiem „zwierzchność Domu Habsburgów nad Brandenburgią można uważać za wygasłą"

„Król-sierżant” Fryderyk Wilhelm I (1713-1740) przemienił zaś Prusy „w korpus gwardyjski, postawił na nogi armię w sile 66 tysięcy i zgromadził skarb w sumie

\footnotetext{
2 Tamże, s. 356.
}

3 J. Donoso Cortes, Lettres politiques sur la situation de la Prusse en 1849, [w:] tegoż, Oeuvres, t. 2, Paris 1862, s. 1-115 [dalej cytowane jako Lettres politiques].

4 Tegoż, Lettres politiques, s. 82. W innym miejscu stwierdzał: „Historia tej rodziny [Hohenzollernów] od Wielkiego Elektora po obecnie panującego Fryderyka Wilhelma IV jest najbardziej cudowna ze wszystkich historii”. Tamże, s. 65.

5 Tamże, s. 88. 
80 milionów [talarów]"'. Panowanie Fryderyka II (1740-1786) było w ocenie Donoso „wypełnieniem [pruskiej] historii”: „poprzez wyrwanie Austrii Śląska postawił on swoje królestwo na poziomie cesarstwa, a biorąc główny udział w pierwszym rozbiorze Polski, pomścił wszystkie wcześniejsze porażki pruskie i dawne upokorzenia"7. Warto zauważyć w tym miejscu, że hiszpański pisarz nie dysponował raczej gruntowną wiedzą dotyczącą stosunków polsko-pruskich. Charakterystyczne było jego milczenie podczas omawiania osiągnięć politycznych Wielkiego Elektora na temat traktatów welawsko-bydgoskich (1657), dzięki którym Hohenzollern uzyskał suwerenność w Księstwie Pruskim, które to potem stało się podstawą starań o królewską koronę (Fryderyk III w 1701 r. koronował się w Królewcu nie w Berlinie jako „król w Prusach”).

Polska - a konkretniej książęta piastowscy - nie istnieją również we fragmencie, w którym hiszpański dyplomata omawiał sprowadzenie Krzyżaków do Prus w XIII w ${ }^{8}$. Równie zaskakujące jest jego twierdzenie o Prusach jako o „w większości narodzie słowiańskim”" Swoją drogą Donoso dostrzegał ciągłość między dawnymi pogańskimi Prusami a Prusami rządzonymi przez Hohenzollernów. Pogańskie Prusy „reprezentowały azjatycki poganizm przeciw europejskiemu chrystianizmowi”. Po 1525 r. Prusy zaś „mają misję podobną, aczkolwiek różną w formie” - „wyrwać [chrystianizmowi] wnętrzności stając się protestanckimi” ${ }^{10}$. Rok 1525 był w ocenie hiszpańskiego autora data przełomową w dziejach Prus, momentem, w którym „zaczyna się prawdziwa historia Prus”11, ale nie z powodu przyjęcia przez Albrechta Hohenzollerna zależności lennej wobec Korony Polskiej, tylko z powodu apostazji ostatniego wielkiego mistrza krzyżackiego w Prusach i przyjęcia przez niego protestantyzmu. „Prusy żyją przez protestantyzm, dzięki protestantyzmowi i dla protestantyzmu" ${ }^{12}$ - stwierdzał Donoso. Zaraz jednak dodawał, że chociaż protestantyzm jest „tajemnicą chwały” Prus, będzie również „tajemnicą ich śmierci” ${ }^{13}$. Dla katolickiego myśliciela politycznego protestantyzm zawsze był zarodkiem śmierci, rozkła-

\footnotetext{
Tamże.

Tamże.

8 Tamże, s. 83.

9 Tamże.

10 Tamże, s. 86.

11 Tamże.

12 Tamże, s. 90.

13 Tamże.
} 
du. Te słowa o dominującym w Prusach protestantyzmie i tylko tymczasowej jego roli jako spoiwa państwa, należy zestawić ze słowami napisanymi przez Donoso dwa lata później w liście do hiszpańskiej królowej Marii Krystyny: „Narody osłabiają się i umierają z głodu, gdy nie otrzymują od Kościoła swojego chleba powszedniego" ${ }^{14}$. Prymat katolicyzmu w rzeczywistości religijnej, jak i społecznej oraz politycznej był dla hiszpańskiego tradycjonalisty rzeczą oczywistą.

Erozja spowodowana przez protestantyzm, choć pewna, nie objawi się w przypadku Prus szybko. Początek XIX w. byl, jak podkreślał hiszpański autor, kolejną epoką systematycznego wzrostu znaczenia monarchii pruskiej na arenie międzynarodowej. Z epoki wojen napoleońskich, które rozpoczęły się dla Prus traumatyczna klęską pod Jeną i Auerstedt, państwo Hohenzollernów wyszło dzięki reformom Steina - Hardenberga wzmocnione - przygotowane do podjęcia kluczowej roli politycznej na obszarze całych Niemiec. Świadczyło to o tym, że rząd pruski po 1806 r., a zwłaszcza po 1815 r., okazał się „bardziej inteligentny i bardziej doświadczony aniżeli inne [...] Aby zreformować Niemcy mając jak najwięcej autorytetu, Prusy zaczęły od zreformowania samych siebie, ustanowily jednolitość miar i wag i zniosły cła wewnętrzne"15. Donoso Cortes zwracał szczególną uwagę na dwa czynniki, które po 1815 r. odegrały decydującą rolę w systematycznym wzroście znaczenia Prus w Niemczech i w Europie. Pierwszym z nich była „rewolucja w ładzie politycznym”, jaką były postanowienia kongresu wiedeńskiego w odniesieniu do Prus ${ }^{16}$. Przypomnijmy, że w Wiedniu oprócz powrotu Wielkopolski w granice monarchii Hohenzollernów (jako Wielkiego Księstwa Poznańskiego) zadecydowano również o znacznym przyroście terytorialnym tego państwa głównie na kierunku niemieckim (przyłączenie Nadrenii, Westfalii, części Saksonii), wyznaczając niejako dalszy kierunek ekspansji Prus. W ocenie Donoso te przesunięcia terytorialne oraz powołanie Związku Niemieckiego (formalnie pod dominacją Habsburgów) były równoznaczne ze „zniszczeniem państw niemieckich” oraz oddaniem w pruskie ręce „berła politycznej dominacji [ w Niemczech]” ${ }^{17}$. Na rzecz Prus działała również „unia celna w ładzie ekonomicznym”, która zapewniła im „gospodarcze kierownictwo w Niemczech”"

\footnotetext{
14 List J. Donoso Cortesa do królowej Marii Krystyny z 26 XI 1851, [w:] tegoż, Oeuvres, t. 2, s. 166.

15 Tamże, s. 96.

16 Tamże, s. 90.

17 Tamże.

18 Tamże.
} 
W ten sposób Donoso określał powstały w 1834 r. pod egidą Prus ogólnoniemiecki Związek Celny. Jego powstanie - jak pisał hiszpański dyplomata - było zarówno owocem „tendencji naturalnej w cywilizacji europejskiej, jak i przejawem „niejasnych pragnień jedności wstrząsających zawsze Niemcami”. Przede wszystkim zaś stały za nim „inteligencja i ambicje Prus" ${ }^{19}$.

Swojej wysokiej oceny pozycji (nie tylko politycznej) Prus Donoso nie zmienił również w okresie Wiosny Ludów, której wstrząsy nie ominęły przecież państwa Hohenzollernów. Na początku marca 1849 Donoso wyjaśniał, dlaczego jego zdaniem Prusy „trzymają w swoich rękach los Niemiec” - „na skutek swojej zaawansowanej cywilizacji, przez siły materialne, które mają do dyspozycji, przez swoje śmiałe koncepcje ekonomiczne, przez swój rosnący dobrobyt i przez wiarę - inspirującą także innych - w swoje przeznaczenie i w swoje szczęście"20. Dyplomatyczna służba J. Donoso Cortesa nad Sprewą (1849) przypadła na czas, gdy w Prusach wstrząsy Wiosny Ludów przeszły już swoją kulminacyjną fazę. Od końca 1848 r. król Fryderyk Wilhelm IV oraz rząd pruski przeszli do kontrofensywy, aczkolwiek jej celem nie było całkowite odwrócenie (do czego namawiali go doradcy z konserwatywnej „kamaryli”) przemian politycznych i ustrojowych, jakie zaszły w Prusach po marcu 1848 r. Pruskie Zgromadzenie Narodowe zostało zmuszone do przeniesienia swoich obrad z Berlina do Brandenburga, oktrojowana została konstytucja, a w $1849 \mathrm{r}$. wprowadzono cenzusowe prawo wyborcze do pruskiego parlamentu (obowiązujące aż do 1918 r.). Krótko mówiąc, był to kurs polityczny, który nazywany jest przez współczesnych badaczy tego zjawiska reformistycznym konserwatyzmem ${ }^{21}$. Po oktrojowaniu konstytucji (zatwierdzonej przez pruski parlament w 1850 r.) największymi przegranymi okazali się radykałowie i demokraci, większość pruskich środowisk liberalnych (zwłaszcza tzw. prawe centrum) czuła się właściwie usatysfakcjonowana takim obrotem sprawy.

Równolegle w 1849 r. Prusy dynamizowały swoją politykę niemiecką, zgodnie z deklaracją Fryderyka Wilhelma IV, który w gorących dniach marca 1848 r. zapewniał „swoich drogich berlińczyków”, że „odtąd Prusy przechodzą w Niemcy”. 27 III 1849 r. obradujące we Frankfurcie nad Menem ogólnoniemieckie Zgromadzenie Narodowe większością czterech głosów zadecydowało, że przyszła Rzesza będzie

\footnotetext{
19 Tamże, s. 98.

20 Tamże, s. 8.

21 M. Niedzielska, Rządzący i rządzeni. Państwo wobec opozycji politycznej w prowincji pruskiej w latach 1848-1862, Toruń 2015, s. 69-71.
} 
miała ustrój monarchiczny. Następnego dnia stosunkiem głosów 290 do 248 Parlament Frankfurcki jako przyszłego cesarza niemieckiego wskazał Fryderyka Wilhelma IV. 3 IV 1849 r. delegacja Zgromadzenia Narodowego przybyła do Berlina ofiarować cesarską koronę władcy Prus. W jego ocenie zaś była to korona „wymyślona, ulepiona z błota i gliny"22. Decyzja Hohenzollerna - ogłoszona 28 IV 1849 r. - była odmowna, jednak towarzyszyła jej gotowość Fryderyka Wilhelma IV (której dawał wyraz w swojej korespondencji) „przyjęcia natychmiast urzędu władzy centralnej z rąk królów i książąt [niemieckich]”23. Fryderyk Wilhelm IV już w grudniu 1848 r. z dużym sceptycyzmem zapatrywał się na zapadające we frankfurckim kościele św. Pawła decyzje, oddające polityczne pierwszeństwo w Niemczech państwu pruskiemu. Już pod koniec 1848 r. władca Prus dawał wyraz nie tyle swojej niechęci, co obrzydzeniu na myśl o objęciu w przyszłości cesarskiej korony Rzeszy, ofiarowanej mu przez niemieckie Zgromadzenie Narodowe. Byłoby to jego zdaniem niczym innym jak nałożenie na siebie „psiej obroży”. „Syn więcej niż dwudziestu czterech władców, elektorów i królów [...] nie może stać się niewolnikiem rewolucji” - stwierdzał wiosną 1849 r. Fryderyk Wilhelm IV. W swojej korespondencji zapewniał o tym nie tylko poszczególnych władców państw niemieckich, lecz także swojego potężnego szwagra, cara Mikołaja $\mathrm{I}^{24}$.

Wspomniany przez króla pruskiego plan „przyjęcia władzy centralnej” w Niemczech, ale z „rąk królów i książąt” przybrał w latach 1849-1850formę starań Berlina o stworzenie pod egidą Hohenzollernów rodzaju federacyjnego związku państw o ustroju konstytucyjnym. W tym okresie wykonawcą tych planów był bliski doradca Fryderyka Wilhelma IV minister Joseph Maria Radowitz (jako jeden z nielicznych przedstawicieli pruskiej elity władzy był on katolikiem). W tym samym czasie (wiosną i latem 1849 r.) wojska pruskie tłumiły ostatnie demokratyczne powstania w Saksonii, Badenii oraz Palatynacie Reńskim. Pruskie plany stworzenia pod egidą Hohenzollernów „unii królów i książąt niemieckich” (w 1850 r. nazwanej Unią Erfurcką - od miejsca przyjęcia konstytucji dla tego mającego powstać tworu państwowego) spotykały się ze zdecydowaną opozycją na arenie międzynarodo-

22 D.E. Barclay, Anarchie und guter Wille. Friedrich Wilhelm IV. und die preußische Monarchie, Berlin 1995, s. 280.

23 Tenże, Preußen und die Unionspolitik 1849/ 50, [w: Die Erfurter Union und das Erfurter Palament 1850, red. G. Mai, Köln 2000, s. 62.

24 Tamże, s. 60 (również przytoczone cytaty). Por. również D.E. Barclay, Anarchie und guter Wille, s. 279-280. 
wej. Od początku zdecydowany sprzeciw wobec tego typu projektów zgłaszał rząd austriacki kierowany przez dynamicznego kanclerza, ks. Feliksa Schwarzenberga. W tej sprawie mógł on liczyć na poparcie ze strony Rosji. Mikołaj I od początku $\mathrm{z}$ dużą rezerwą zapatrywał się na politykę Prus zmierzającą do utworzenia pod swoim patronatem „ściślejszego” Związku (pod nazwą Rzeszy Niemieckiej). Już w połowie lutego 1849 r. rosyjski ambasador w Prusach (Peter von Meyendorff), odnosząc się do tej koncepcji, stwierdzał: „Nie możemy dopuścić, aby doszło do takiego stopienia" ${ }^{25}$.

W lipcu 1849 r. austriacki ambasador w Berlinie (Anton von Prokesch-Osten) ostrzegał pruskiego premiera, że „jedność [Niemiec] jest do osiągnięcia albo przez rewolucję oddolną, albo odgórną, bądź przez obie naraz jednocześnie"26. Podobne stanowisko - co do zasady powstania jednolitego państwa niemieckiego - zajmowały nie tylko Rosja, ale również Wielka Brytania. W tym samym czasie, brytyjski ambasador w Prusach określał bowiem politykę Radowitza w Niemczech jako „związek $\mathrm{z}$ rewolucją?" ${ }^{27}$. Dużą część z tych wydarzeń J. Donoso Cortes mógł śledzić z bliska jako hiszpański poseł przy pruskim dworze. W listach dawał wyraz swojemu stałemu przekonaniu, że idea politycznej jedności Niemiec jest „ideą potępioną przez rozsądek i przez historię". Jednak niemiecka demokracja, podchwytując tę ideę, postąpiła tak ,jak wszędzie” - „pokochała to, co absurdalne, gigantyczne i niemożliwe”28. Nie jedność, ale istnienie „germańskiego chaosu” było zdaniem hiszpańskiego dyplomaty kategorią najlepiej obrazującą stan Niemiec w 1849 r. Nie tylko zresztą w odniesieniu do zagadnień politycznych. Wspomniany „germański chaos” ogarniał właściwie wszystkie sfery życia: „z punktu widzenia religii koegzystują w nim: katolicyzm, protestantyzm, mistycyzm, racjonalizm i ateizm; z punktu widzenia politycznego: konstytucjonalizm, absolutyzm i demagogia; z punktu widzenia społecznego: feudalizm i socjalizm; wreszcie z punktu widzenia terytorialnego - duża

25 K. Canis, Vom Staatstreich zur Unionspolitik. Die Interpendenz von innerer, deutscher und äußerer Politik der preußischen Regierung am Ende der Revolution 1848/49, [w:] Demokratie, Liberalismus und Kontrrevolution. Studien zur deutschen Revolution von 1848/49, red. W. Schmidt, Berlin 1998, s. 151.

26 Tenże, Die preußische Gegenrevolution und Hauptelemente der Regierungspolitik von Ende 1848 bis 1850, [w:] Revolution in Deutschland und Europa 1848/49, red. W. Hardtwig, Göttingen 1998, s. 181.

27 Tenże, Vom Staatsstrech zur Unionspolitik, s. 156. Szerzej na ten temat zob. W.D. Gruner, Die europäischen Mächte und die deutsche Frage 1848-1850, [w:] Die Erfurter Union und das Erfurter Unionsparlament 1850, s. 271-305.

28 J. Donoso Cortes, Lettres politiques, s. 31. 
liczba narodów zjednoczonych swoim pochodzeniem i oddzielonych przez swoje tradycje i historię"29.

Emanacją tego chaosu była również działalność parlamentu frankfurckiego oraz uchwalona przez niego konstytucja. O niemieckiej konstytuancie obradującej we Frankfurcie nad Menem Donoso nie wypowiadał się pochlebnie. Była ona dla niego „zgromadzeniem złożonym z politycznych somnambulików”, które „dekretuje wszystko, co mu przychodzi do głowy”, a „zabiera głos, by proklamować jedynie absurdy" ${ }^{30}$. Tak opisany sposób działania frankfurckiego parlamentu przełożył się na treść uchwalonej w 1849 r. przez niego niemieckiej konstytucji: „dla jednych jest ona symbolem wolności, dla drugich symbolem powiększenia własnej potęgi; dla wszystkich - streszczeniem niewyraźnych, nowych, wspaniałych idei, które poruszają wyobraźnię i panują nad sercami, gdy ludy stoją u progu wielkich zmian i wielkich wstrząsów" ${ }^{31}$. Według hiszpańskiego tradycjonalisty w przypadku obrad parlamentu frankfurckiego i uchwalonej przezeń konstytucji nie chodziło tylko o zabawny przejaw nierealistycznego myślenia „setki profesorów”, wedle przypisywanego Otto von Bismarckowi aforyzmu: „Ein Hundert Professoren, Vaterland, Du bist verloren!” (Setka profesorów, Ojczyzno - jesteś zgubiona!). Sprawa była zdaniem Donoso o wiele poważniejsza, bowiem działalność frankfurckiego parlamentu odzwierciedlała coś głębszego, a mianowicie „mistycyzm demagogiczny” charakterystyczny dla Niemców, który streszcza się w jednym słowie: „idea”. „Idea jest w świecie moralności tym, czym elektryczność w świecie fizyki - siłą nienamacalną, tajemniczą, której nic się nie przeciwstawia i nic nie stawia oporu. »Idea « - to korodująca kropla, która natychmiastowo niszczy organizm społeczny; »idea « nie jest niczym innym jak $\gg$ złem $\ll$, »złem absolutnym $\ll$, złem par excellence, przybierającym obecnie - by lepiej walczyć - tą formę, pod którą stoczy swoją ostatnią bitwę; »idea «, która jest demokracją lub złem uczynionym $w$ »legion «, złem wcielonym w tłum" ${ }^{32}$. W tym

\footnotetext{
29 Tamże, s. 16.
}

30 Tamże, s. 49. W innym miejscu Donoso pisał: „Parlament frankfurcki - nie wiadomo skąd przyszedł, nie wiadomo przez kogo został zwołany [...]. Na miejsce nieobecnej jedności tworzy symbole, mianował wikariusza cesarza, którego nie ma, ministra wikariusza, który jest wikariuszem nie wiadomo kogo". Tamże, s. 20.

31 Tamże, s. 48. Także po powrocie z berlińskiej placówki Donoso wyrażał swój krytycyzm, jeśli nie pogardę, wobec ogólnoniemieckiej konstytuanty. W 1850 r. mówił o parlamencie frankfurckim w Kortezach: „Niemcy umieściły go jak bóstwo w świątyni i te same Niemcy zezwoliły mu umrzeć jak prostytutce w karczmie”. J. Donoso Cortes, Oeuvres, t. 1, s. 406.

32 Tenże, Lettres politiques, s. 49. 
kontekście hiszpański dyplomata wskazywał na rewolucyjny potencjał tkwiący w filozofii Georga Wilhelma Hegla. Donoso nie wahał się określić heglizm mianem „najważniejszej i dezorganizującej przyczyny radykalnego zwrotu, który nabierają rewolucje po tej stronie Renu"33.

„Demagogiczny mistycyzm” przyprawiony równie rewolucyjnym heglizmem sprawił, że w Niemczech „rewolucja zawładnęła umysłami, a idee komunistyczne panują w zdeprawowanych sercach i w ateistycznych duszach” ${ }^{34}$. „Demagogia przeniknęła naród niemiecki aż do szpiku kości" ${ }^{35}$, to zaś w kontekście stricte politycznym oznaczało, że z gruntu nierealistyczne dążenie do przezwyciężenie „germańskiego chaosu" stało się na początku 1849 r. postulatem chętnie podchwytywanym przez większą część niemieckiej opinii publicznej. „Wszystkie drogi prowadzą do cesarstwa i wszyscy [Niemcy] idą ku niemu różnymi drogami. Pozostaje tylko obecnie do rozstrzygnięcia, kto będzie ostatecznym panem tego olbrzymiego cesarstwa niemieckiego: demokracja czy monarchia, jakiś nieznany klubowy demagog czy też król

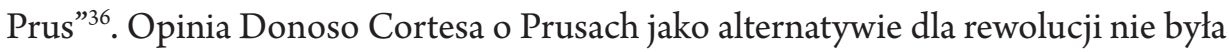
wcale jednoznaczna. Na początku 1849 r. hiszpański dyplomata zauważał bowiem, że państwo Hohenzollernów - „podobnie jak wszystkie inne państwa” - jest podzielone na trzy części: tych, co nie chcą zmian, tych, co chcą „wolności konstytucyjnej mądrze postępowej”, wreszcie trzecia grupa dąży do ustanowienia „republiki demokratycznej”. Co ciekawe, w tej grupie Donoso widzi Polaków „zawsze gotowych do rewolty i do wszczęcia pożaru”, oprócz tego zaś Żydów, robotników i studentów oraz ludzi pióra ${ }^{37}$. Na to nakładała się nie zawsze spójna i konsekwentna polityka rządu pruskiego, a zwłaszcza króla Fryderyka Wilhelma IV. Donoso był krytyczny wobec tego władcy. Tego samego Hohenzollerna, którego chwalił później jako „Augusta Germanii”, w odniesieniu do przemian ustrojowych w Prusach epoki Wiosny Ludów (przede wszystkim w kontekście nadania monarchii charakteru konstytucyjnego) ostro krytykował. Jego zdaniem postępowanie króla Prus w tej kwestii udowadniało, że „brakuje mu zdrowego rozsądku, a jego umysł ciągle miota się między tym, co wzniosłe, a tym, co ekstrawaganckie" 38 .

\footnotetext{
33 Tamże, s. 9.

34 Tamże, s. 58.

35 Tamże, s. 48.

36 Tamże, s. 67.

37 Tamże, s. 8-9.

38 Tamże, s. 32.
} 
Hiszpański dyplomata był pełen uznania dla króla Prus za rozwiązanie pruskiego parlamentu, który „nie chciał uznać Boga jako źródła władzy”. To czego nie aprobował to konstatowany przezeń fakt, że „ten nieszczęsny władca nie dostrzegł, że przepaść, która za jednym razem pochłonęła szlachtę i burżuazję, otwiera się także przed nim"39. W 1848 r. to nie tyle mądra, dalekowzroczna polityka Fryderyka Wilhelma IV uratowała Prusy, ile armia - „najwierniejsza i najbardziej zdyscyplinowana w Europie” - oraz administracja, która „przed paroma laty była podziwiana w całej Europie" ${ }^{\prime 4}$. Dostrzegany przez Donoso flirt Fryderyka Wilhelma IV z rewolucją polegał przede wszystkim na uleganiu przez króla Prus pokusie absolutyzmu ${ }^{41}$. Według hiszpańskiego tradycjonalisty polityka Fryderyka Wilhelma IV w Prusach dążyła do tego, by za pomocą „poruszeń ludowych” doprowadzić do sytuacji, w której „na górze jest tylko król, a na dole tylko lud - bez żadnych pośredników”"22. Ta wizja znajduje swoją najlepszą ilustrację w pruskiej konstytucji. W tym kontekście Donoso oceniał oktrojowaną w grudniu 1848 r. pruską konstytucję, która - jak pisał - „nie jest, jak niektórzy sądzą, dziełem strachu, jest raczej rezultatem najgłębszej kalkulacji: to doskonała realizacja systemu politycznego króla [...] z jednej strony jest absolutystyczna, a z drugiej demokratyczna"43. W ocenie hiszpańskiego obserwatora pruska konstytucja oktrojowana przez Fryderyka Wilhelma IV przy gromkim sprzeciwie ugrupowań demokratycznych i radykalnych (ale już nie wszystkich liberałów) była tak bardzo liberalna, że nawet hiszpańska konstytucja z 1812 r. (tzw. konstytucja z Kadyksu) w porównaniu z pruską może „uchodzić za reakcyjną”"4.

„Demokratyzm” pruskiej konstytucji polegal przede wszystkim na zgodzie króla Prus na istnienie parlamentu wyposażonego w ograniczone, acz ważne kompetencje (przede wszystkim gdy chodzi o uchwalanie budżetu rząd, administracja i armia odpowiadały tylko przed królem). W tym kontekście bardzo pozytywnie Donoso oceniał oktrojowanie przez Fryderyka Wilhelma IV cenzusowego prawa wyborczego, które jego zdaniem było „najbardziej arystokratyczne w Europie” ${ }^{45}$. W kwietniu 1849 r. hiszpański dyplomata, podsumowując dotychczasową politykę Berlina, pi-

\footnotetext{
39 Tamże, s. 34-35.

40 Tamże, s. $15,35$.

41 Tamże, s. 35.

42 Tamże, s. 34.

43 Tamże, s. 36.

44 Tamże, s. 12.

45 Tamże, s. 79.
} 
sał: „rząd pruski sądzi, że osiągnął wszystko, co należy się monarchii i wszystko, co przynależy demagogii i wmawia sobie, że rozwiązał wszystkie problemy, pokonał wszelkie trudności i ominął wszystkie rafy" ${ }^{46}$. Odrzucenie przez króla Prus korony cesarskiej ofiarowanej mu przez parlament frankfurcki oraz pruskie interwencje zbrojne, które miały miejsce wiosną i latem 1849 r. przeciw ruchom demokratycznym w Saksonii oraz Badenii, wzbudziły nadzieje Donoso, że rząd pruski, który do tej pory „naiwnie sądził, że duch rewolucyjny dotknął Niemcy zaledwie na powierzchni”, obecnie „zaczyna widzieć on rzeczy takimi jakimi są”47. Jak zauważał jednak hiszpański poseł, porażka najbardziej radykalnego skrzydła rewolucyjnego nie oznaczała jednak zwycięstwa sprawy monarchicznej w Niemczech, a na pewno nie była powodem uspokojenia dla mniejszych władców niemieckich, którzy w połowie 1849 r. znaleźli się między Scyllą a Charybdą, „między rewolucją, która ich obali oraz Prusami, które je zmiażdżą przez swoją opiekę nad nimi. Nie pozostaje im więc żaden inny wybór, jak wybór rodzaju śmierci”"48.

Pruskiemu ministrowi spraw zagranicznych (i katolikowi) Josephowi M. Radowitzowi hiszpański dyplomata nie szczędził pochwał, nazywał go „jedną z najbardziej znaczących osobistości naszych czasów, nie tylko w Prusach, Niemczech czy Europie, ale na całym świecie" ${ }^{\prime 9}$. Z drugiej strony uważał, że opracowywana przez niego a firmowana przez pruskiego króla polityka zmierzająca do utworzenia w oparciu o Prusy „unii królów i książąt” zmierza do faktycznej mediatyzacji średnich i mniejszych państw niemieckich. A przynajmniej tych, które leżały na północy Niemiec. Donoso przewidywał bowiem nieuchronny podział Niemiec na część północną i południową. W przypadku utraty wpływów Austrii w Niemczech, Niemcy południowe „połączą się z Francją i ukonstytuują się na podstawie demokratycznej”. Te „Niemcy Południowe” „w żadnym wypadku nie stworzą organicznej jedności z Niemcami Północnymi”, które „już się utworzyły”. Tak bowiem w połowie 1849 r. hiszpański dyplomata oceniał wstępne zabiegi Prus o utworzenie wspomnianej „unii królów i książąt niemieckich" ${ }^{50}$. Pozostawał jeszcze kontekst zewnętrzny przemian politycznych w obrębie Niemiec. Donoso niejednokrotnie zwracał uwagę, że to, co się dzieje w Niemczech (i w tym kontekście polityka Prus) ma kolosalne znaczenie dla całej

\footnotetext{
46 Tamże, s. 31.

47 Tamże, s. 65.

48 Tamże.

49 Tamże, s. 44.

50 Tamże, s. 81.
} 
polityki europejskiej, a w tamtych realiach - również dla polityki światowej. Jeszcze przed ogłoszeniem decyzji Fryderyka Wilhelma IV o odrzuceniu ofiarowanej mu przez parlament frankfurcki korony cesarskiej hiszpański poseł pisał, że jej ewentualne przyjęcie przez Hohenzollerna oznaczać będzie wybuch „wojny powszechnej”, której wynikiem będzie „drugie i ostateczne zatonięcie wielkiej iluzji, którą nazywa się jednością Niemiec"51. Konflikt zbrojny o takiej skali mogły wywołać nie tylko nierozważne decyzje „somnambulików” z parlamentu frankfurckiego, ale również nieroztropna polityka niemiecka Prus, jeśli by jej celem - a tak sądził Donoso - miała być trwała destrukcja powołanego do życia na kongresie wiedeńskim Związku Niemieckiego. W tym kontekście jako mocarstwo, które będzie najbardziej skłonne do interwencji zbrojnej w sprawy niemieckie, a tym samym rozpęta „wojnę powszechną", hiszpański dyplomata wskazywał Rosję. Powstały w 1815 r. Związek Niemiecki był jego zdaniem na równi instrumentem przeciwdziałania ekspansji prądów rewolucyjnych w Niemczech jak i „narzędziem wpływania Rosji na Europę" ${ }^{\text {. }}$.

Ze swojej berlińskiej placówki Donoso pisał, że „berło europejskiej dyktatury przeszło z rąk narodów łacińskich w ręce narodów niemieckich i słowiańskich"53. O wszystkim decydują przemiany polityczne w Niemczech i postawa wobec nich Rosji. Wiosną 1849 r. hiszpański poseł skłaniał się ku opinii, że interwencja rosyjska w Niemczech ,jest nieuchronna”. A interwencja ta „to ogień ogarniający naraz wszystkie zakątki Europy a może nawet i świata; to ogólny kataklizm, który dotknie wszystkie narody, a którego one do tej pory nie oglądały. Europa wyjdzie z niego jak przewidywał Napoleon - albo republikańska, albo kozacka, jeśli nie katolicka. Oto trzecie wyjście, którego nie przewidział przenikliwy geniusz wielkiego dowódcy i wielkiego proroka" ${ }^{4}$. Pobyt nad Sprewą, który okazał się epizodem w biografii Juana Donoso Cortesa, był jednak ważnym doświadczeniem dla jego myśli politycznej. Także po powrocie do Hiszpanii akcentował swoje przeświadczenie, że miejsce, w którym się znalazł w 1849 r. jako poseł, nie było odległą peryferią, ale odwrotnie: najważniejszym dla całej Europy teatrem politycznych decyzji. W 1850 r. omawiając w Kortezach ogólną sytuację polityczną w Europie, stwierdzał: „nie mogę mówić o Europie bez mówienia o Niemczech; nie mogę mówić o Niemczech bez mówienia

\footnotetext{
51 Tamże, s. 22.

52 Tamże, s. 28. O Związku Niemieckim jako rosyjskim „narzędziu wpływania na Europę” Donoso mówił w 1850 r. w hiszpańskim parlamencie. Por. J. Donoso Cortes, Oeuvres, t. 1, s. 396.

53 Tenże, Lettres politiques, s. 42.

54 Tamże, s. 51.
} 
o Prusach, które je reprezentują; nie mogę mówić o Prusach bez mówienia o ich królu, którego wspaniałe właściwości pozwalają mi nazwać go Augustem Germanii" "55. Znacząca rola Niemiec polegała jego zdaniem również na tym, że to tam była opracowywana najnowsza i najgorsza forma rewolucyjnego zagrożenia - socjalizm. W tym samym przemówieniu zwracał się do hiszpańskich parlamentarzystów: „wiedzcie, że socjalizm rozgrywa się w trzech wielkich teatrach: we Francji, gdzie są uczniowie i tylko uczniowie; w Italii, gdzie są wykonawcy i tylko wykonawcy; w Niemczech, gdzie są kapłani i mistrzowie"56.

Powyższe uwagi potwierdzają przenikliwość hiszpańskiego tradycjonalisty jako obserwatora europejskiej, a w szczególności niemieckiej sceny politycznej w XIX w. Zważywszy na to, że właśnie na obszarze państwa Hohenzollernów kształtował się tzw. socjalizm naukowy Karola Marksa i Fryderyka Engelsa („kapłani i mistrzowie”), a w kolejnych dziesięcioleciach tego stulecia niemiecka socjaldemokracja urośnie do największej partii socjalistycznej na kontynencie, jego spostrzeżenia okazały się trafną prognozą. Analogiczną wartość mają przedstawione tutaj analizy znaczenia monarchii Hohenzollernów zarówno dla Niemiec jak i całej Europy. Choć pewną przesadą tchną słowa Donoso Cortesa o Fryderyku Wilhelmie IV, to jednak hiszpański tradycjonalista nie mylił się w tym, że Prusy jako mocarstwo europejskie weszły na ścieżkę trwałego wzrostu. Wydawać taki sąd rok po Wiośnie Ludów, oznaczało wiedzieć bardzo dużo o Prusach i Związku Niemieckim. Z drugiej strony hiszpański myśliciel, podobnie jak wielu zachodnich historyków zajmujących się dziejami Prus w kolejnych stuleciach, nie dostrzegał prawdziwych korzeni wielkości Prus, której by nie było bez upadku Rzeczypospolitej.

Prof. dr hab. Grzegorz Kucharczyk

Instytut Historii Polskiej Akademii Nauk

Rynek Starego Miasta 29/31

00-272 Warszawa

gregork@man.poznan.pl

Nadesłany 3 VI 2020

Nadesłany po poprawkach recenzyjnych 8 VIII 2020

Zaakceptowany 10 VIII 2020

55 J. Donoso Cortes, Oeuvres, t. 1, s. 395.

56 Tamże, s. 388. 


\section{Summary}

Juan Donoso Cortes's stay in Berlin in 1849 as a Spanish envoy at the Prussian court posed an opportunity for close observation of the developments of the German and Prussian Revolution of 1848/49. In the eyes of the Spanish diplomat, the Prussian monarchy was a state which, following the Napoleonic wars, rose in the ranks of the European political system. According to him, this rise should have been attributed not only to the territorial growth after 1815 but also the economic expansion of Prussia. Donoso Cortes was rather sceptical in his evaluation of the chances for uniting Germany. He referred to the "German chaos" which manifested itself in the political, religious and social context. In his opinion, the Prussian policy during the Revolutions in $1848 / 49$ was unclear. On the one hand, the Prussian government fought the revolution (for example, by dissolving the Prussian parliament); on the other hand, it approved of important "revolutionary" changes. In this respect, he indicated the fact that Frederick William IV of Prussia imposed the constitution in late 1848. Cortes was of a very high opinion of the king of Prussia for rejecting the imperial crown suggested in April 1849 by the parliament in Frankfurt. The decision deterred the threat of Russian intervention in Germany which soon could have transformed into a "general war". 